\title{
Application of Google earth in carbon assessment and monitoring in agroforestry: a study from Ratanpur, Nepal
}

\begin{abstract}
The carbon assessment and monitoring in small scale forests like agroforests are difficult tasks but it creates enormous opportunity as carbon credit. This study aims to assess carbon sequestration potential in agroforestry including soil carbon using google earth imageries Agroforestry of Ratanpur village in Tanahun district Nepal was selected as the study site. Total agroforests of 19 farmers were selected as the experimental and no agroforests area of 4 farmers were selected as the control site. The high resolution imageries of 2020 and 2015 were acquired from Google earth pro. The digitization was done to classify the image into agriculture, agroforestry, natural trees, settlement areas and others. Total enumeration was done to measure the diameter and height of the plants (tree species) planted in the agro-forest. Moreover, total 69 soil samples were collected from 0-10, 10-20 and 20-30 $\mathrm{cm}$ depth. The biomass was calculated using Chave et al. equation while soil carbon was analyzed using Walkley Black method. The biomass was converted into carbon which was used to calculate mean annual carbon increment. The result showed the highest carbon stock was $17.6 \mathrm{~kg} /$ stand of Paulownia tomentosa. Total carbon sequestration potential was $2057.689 \mathrm{~kg}$ and its monetary value was US\$ 30.863 . The mean soil carbon stock of agroforest was higher 52.92 ton/ha than this of 50.3 ton/ha in agriculture site. The map showed it was 7.63 ha agroforest in map of 2020. The overall accuracy of map of 2015 was $90.91 \%$ with Kappa coefficient 0.86 but these values were $80.65 \%$ and 0.74 respectively of map of 2020. One-way ANOVA and Post hoc test showed that there was significant difference in species wise carbon stock per stand at $95 \%$ confidence level. The research will be useful to understand the carbon stock in agroforestry practices.
\end{abstract}

Keywords: agroforestry, plantation, carbon sequestration, land use land cover
Volume 6 Issue 6 - 202I

\author{
Srijana Karki,' Ram Asheshwar Mandal, ${ }^{2}$ \\ Bishnu Hari Pandit ${ }^{\prime}$ \\ 'Kathmandu Forestry College, Tribhuvan University, Nepal

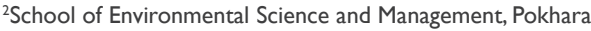 \\ University, Nepal
}

\author{
Correspondence: Ram Asheshwar Mandal, Kathmand \\ Forestry College, School of Environment Science and \\ Management, Pokhara University, Nepal, \\ Email ram.mandal@gmail.com
}

Received: October 16, 2021 | Published: November 15, 202

\section{Introduction}

\section{Background}

According to definition given by Ellis et al., ${ }^{1} \mathrm{Lal},{ }^{2}$ agroforestry is the system of mixture of two or more land use and land cover practice where the forestry activities are the prime one. The statistics showed that approximately 630 million ha land is potential for agroforestry activities which may be able to sequestrate around $586 \mathrm{Mt} \mathrm{C}$ by $2040 .{ }^{3}$ It is estimated that $0.29 \mathrm{MgC} / \mathrm{ha} / \mathrm{yr}$. in West Africa, $15.29 \mathrm{MgC} / \mathrm{ha} / \mathrm{yr}$. in Puerto Rica, $161.52 \mathrm{MgC} /$ ha in Philippines $287.9 \mathrm{C} / \mathrm{t} / \mathrm{ha}$ in Indonesia, 3.8- $4.82 \mathrm{t} / \mathrm{ha} / \mathrm{yr}$ carbon has been stocked in agroforestry in India. ${ }^{4}$

Carbon sequestration is the process of removal of carbon from the atmosphere. ${ }^{5}$ One of the important examples of carbon sequestration is reducing deforestation and forest degradation, sustainable forest management as well as plantation. Globally, around $1-4$ billion $\mathrm{t} \mathrm{CO}_{2}$ can be reduced through minimizing and stopping deforestation and forest degradation. ${ }^{6,7}$ Agroforestry is one of the important practices which can contribute to sequestrate the carbon, meet the demand of basic forest products as well as reduce the deforestation and forest degradation. $^{8-10}$

The monitoring reporting and verification is one of the important components of carbon credit $^{11,12}$ under the Reducing Emission from Deforestation and Degradation (REDD+) mechanism. This needs the reliable method of assessment and monitor carbon in order to determine the carbon credit. Importantly, REDD+ mechanism emphasizes on the application of remote sensing and GIS in monitoring the carbon credit in the forest. ${ }^{13}$ The spatial and temporal change detection considered as the appropriate way to monitor the forest carbon; ${ }^{14}$ Rawat \& Kumar. ${ }^{15}$ If the high resolution imageries are available on Google Earth platform which is freely available the change detection in land use and land cover will be more easier. ${ }^{16}$ Countries like India, Bangladesh, and Pakistan including Nepal are practicing the small scale plantation as agroforestry system where the carbon assessment and monitoring is difficult. Nepal also has been practicing several model of carbon sequestration and agroforestry practices. In this context, there is big challenge to monitor and assess the carbon sequestration in small scale forestry like agroforest. However, comparison of features in two periods of imageries is becoming popular method of carbon assessment and monitoring. ${ }^{17}$ This change detection will be useful techniques to quantify and monitor the carbon stock change in agroforests. ${ }^{18}$ However, there is limited study regarding this. Thus, this research was objectively conducted to assess carbon sequestration potential in agroforests applying google earth high resolution imageries.

\section{Rational and justification}

The agroforest is the best example of carbon sequestration in small scale forestry. This can meet the criteria to trade the carbon but monitoring is accreditation and monitoring is difficult because it is costly. The owner of such small scale agro-forest cannot afford the accreditation and monetary cost. In this context, application of google earth imageries is cheap, easy and convenient method to monitor the carbon. The high resolution imageries also available on google earth platform. The forest and other non-forest areas can be delineated easily on digitized of imageries of different time period which can be used as the change in forest areas in the farm. This types of change 
can be used as carbon additionality which is one of the important criteria of REDD+ activities. However such methods are not explored to research purpose widely. Thus, this research is essential to show the application of google earth imageries to monitor the carbon. This method can be useful for carbon credit buyer to monitor the small scale agroforest.

\section{Materials and methods}

\section{Study site}

The plantation in Ratanpur village was selected as the study site. This village is situated in Bhanu Municipality of Tanahun District,
Nepal. Geographically, the study site is at $28.03^{\circ} \mathrm{N}$ and $84.44^{\circ} \mathrm{E}$ and elevation ranges from 300 to $3300 \mathrm{~m}$ (Figure 1). The average temperature from $11^{\circ} \mathrm{C}$ to $24^{\circ} \mathrm{C}$ and total annual rainfall is around $1377 \mathrm{~mm}$. Hence, the vegetation types are generally subtropical to lower temperate. There are 39 farmers in Ratanour village. Out of this agroforests of 19 farmers were selected as the study site since they have been applying the agroforestry practice. Paulownia tomentosa, Golden michelia, Cinnamomum tamala, Melia azedarach, Mangifera indica, Schima wallichi, Quercus leucotrichophora, Leucaena leucocephala, Choerospondias axillaris, Azadirachta indica plant species are afforested in the farm.

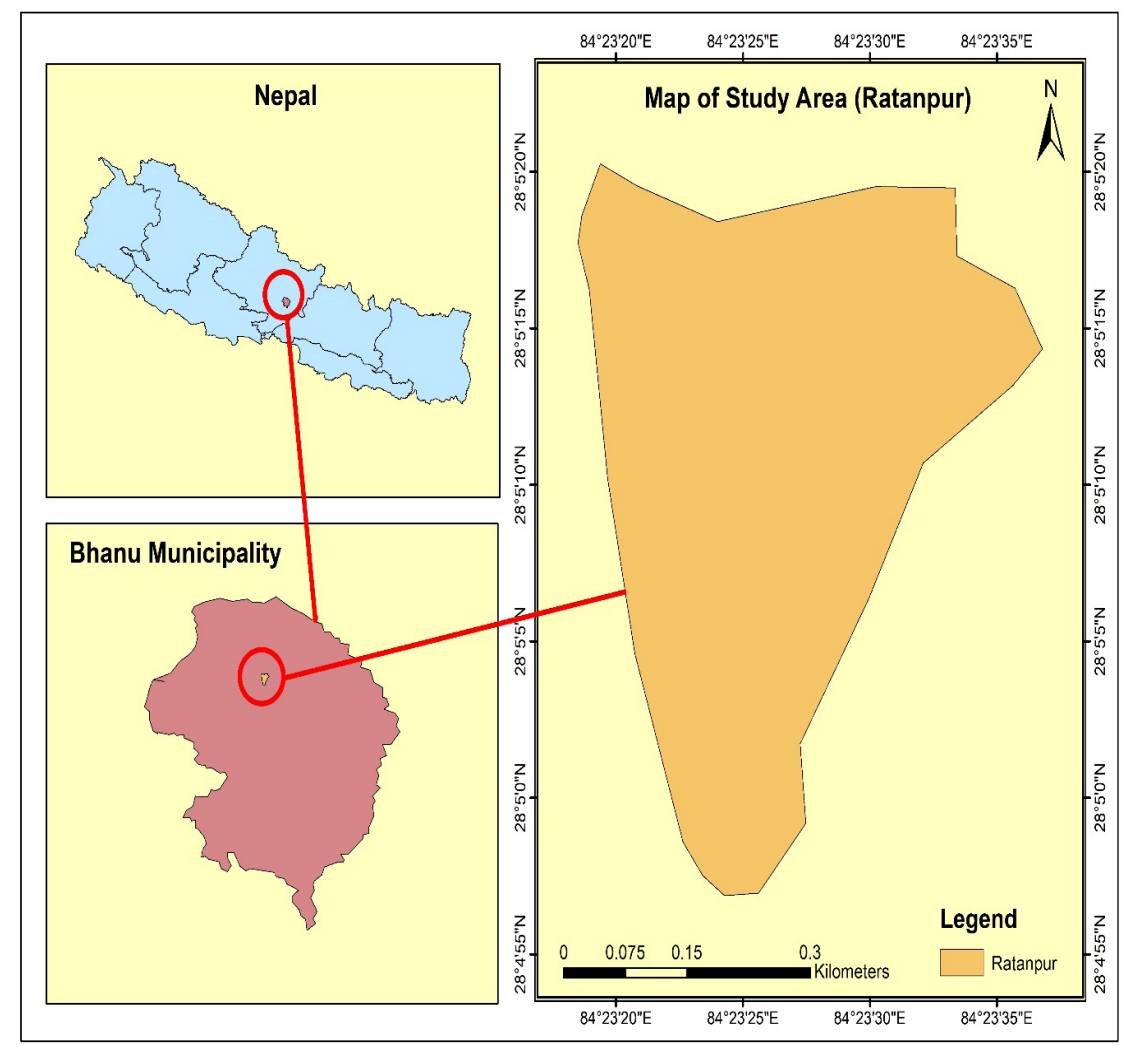

Figure I Map of study area.

\section{Selection of study site and parameter}

The plantation of Ratanpur village is situated in remote area of Lamjung district. The farmers are generally practicing the agriculture in their land but them also practicing agroforestry in the farm particularly in degraded land. They have been planting tree and growing grasses under it so that they can feed the livestock. These agroforestry practices here in rural area are one of motivation site for the people. Moreover, the farmers are interested to work with REDD+ mechanism but they are unknown about accreditation and monitoring process which is prerequisite for this mechanism. Thus this site was selected. The agroforest practices are clearly visible to digitize and delineate agroforest area.

In fact, four parameters are very important to assess the carbon. These parameters are change is forest land, dimeter at breast height, height of the tree and species wise wood density. The field level carbon assessment used to know the carbon sequestration which can be claimed as carbon credit. The above ground, below ground and soil carbon is the estimation parameter which is used to assess the total carbon and its moneatry value.

\section{Data collection}

Primary and secondary data were collected to meet the objectives of the research. Primary data were collected from field observation, direct measurement and laboratory analysis while the secondary data and information were collected from internet surfing, reports, published and unpublished papers. The site was categorized into two main groups namely control site and experimental site. The record of assessment of carbon stock was used as a baseline for experimental site. The plantation area in agroforestry system was considered as the experimental site whereas, Control site (agriculture land) was established near the experimental site in order to compare the carbon increment. For this purpose, total 19 experimental sites and 4 control sites were established to collect the data.

The primary data collection was conducted applying three major steps. They were bio-physical data collection, soil data collection and spatial and temporal data collection.

Bio-physical data collection: The diameter at breast height (DBH: at $1.3 \mathrm{~m}$ height $)$ and height of individual trees $(\mathrm{DBH}>30 \mathrm{~cm})$, pole $(\mathrm{DBH}$ 
$=10-29.9 \mathrm{~cm})$ and sapling $(\mathrm{DBH}>5 \mathrm{~cm})$ were measured in the field Moreover, all the saplings $(1 \mathrm{~cm}<\mathrm{DBH}<5 \mathrm{~cm})$, seedlings, herbs and shrubs were counted in the field and their fresh weights were recorded making the sub-sample to find the moisture content. The age of the plants will be recorded from plantation records as well as the asking with the owners.

Soil data collection: Soil carbon is significantly contributing to total carbon. Total 69 soil samples were collected using known volume soil corer from control site and experimental site maintaining the soil depths of $0-10,10-20$ and $20-30 \mathrm{~cm}$. These samples were placed in the labeled sample bag in order to analyze the carbon in the lab. ${ }^{19}$

\section{Spatial and temporal data collection}

The spatial temporal land use change detection using the Google earth data is of very importance and very useful as spatial temporal of land use detection for land use mapping. ${ }^{20}$ The integration approach between remote sensing and GIS was applied to find the change detection so, the Google earth was as the source of data. The survey was performed throughout the study area using global positioning system (GPS) receiver to prepare the map of the study area. The map of afforested area transformed into kmz file in order to overlaid on Google earth image. The afforested areas of farmers were digitized in the Google earth platform. The historical imagery was used to show the change detection. ${ }^{18}$ Google earth image (high resolution imagery) of 2015 and 2020 was acquired from Google earth professionals (Table 1) in order to digitize on the GIS. ${ }^{2}$

Table I Description of remote sensing data

\begin{tabular}{llll}
\hline Platform & Bands & $\begin{array}{l}\text { Date of } \\
\text { acquisition }\end{array}$ & $\begin{array}{l}\text { Eye altitude } \\
\text { (M) }\end{array}$ \\
\hline $\begin{array}{l}\text { Google earth } \\
\text { professionals }\end{array}$ & RGB & $5 / 8 / 2020$ & 200 \\
$\begin{array}{l}\text { Google earth } \\
\text { professionals }\end{array}$ & RGB & $3 / 5 / 2015$ & 200 \\
\hline
\end{tabular}

\section{Data analysis}

Biophysical data and soil sample analysis: Collected data were analyzed to estimate the carbon stock, mean annual carbon increment and carbon sequestration potential from the agroforestry area of all the farmers and also for all the species planted in the site.

\section{a. Above ground biomass and carbon calculation}

i. Above ground tree and pole biomass calculation: Above Ground Tree Dry Biomass (AGTB) was calculated by using allometric equation $^{22}$ for tree, poles and sapling $(\mathrm{DBH}>5 \mathrm{~cm})$.

$$
\mathrm{AGTB}=0.0509 \times \rho^{2} \mathrm{H}
$$

Whereas AGTB $=$ above ground tree biomass $(\mathrm{kg})$

$\rho=$ dry wood density $(\mathrm{gm} / \mathrm{cm} 3), \mathrm{D}=$ tree diameter at breast height (cm) \& $\mathrm{H}=$ tree height $(\mathrm{m})$

ii. Above ground sapling biomass calculation $(\mathrm{DBH}<5 \mathrm{~cm})$ : The biomass was calculated using the equation compiled by Tamrakar et al., ${ }^{23}$ and its samples were taken to get dry biomass as this allometric equation provides only the fresh weight.

Moreover, the samples of sapling $(\mathrm{DBH}<5 \mathrm{~cm})$, seedling, leaf litter, herbs and grass (LHG) together were carried out in the laboratory to dry. The biomass of sapling, seedling and LHG of sampled area was estimated which was further used to calculate biomass per ha.

\section{b. Below ground biomass and carbon calculation}

i) Root Biomass calculation: Default value i.e. root shoot ratio 0.125 was used $^{24}$ to calculate the root biomass.

ii) Conversion factor: Similarly, the universal conversion factor i.e. 0.47 was used to convert dry biomass to carbon content. ${ }^{25}$

iii) Soil Organic Carbon (SOC): The collected soil samples were brought to the laboratory to determine the carbon content. The soil samples were oven dried at $105^{\circ} \mathrm{C}$ in the laboratory until they reached a constant weight to estimate soil bulk density. ${ }^{26}$

Bulk Density $\left(\mathrm{gm} / \mathrm{cm}^{3}\right)=($ oven dry weight of soil)/ (volume of soil in the core).

The soil samples were analyzed by Walkley \& Black Method ${ }^{27}$ by digestion using Sulphuric acid and oxidized by the Potassium dichromate in laboratory. The soil samples were oven dried at $105^{\circ} \mathrm{C}$ to obtain constant weight.

For calculation of soil organic carbon (SOC), the following formula was used. ${ }^{28}$

$\mathrm{OM} \%=(\mathrm{B}-\mathrm{S}) * \mathrm{~N} * 3 * 100 * 100 * 100 /$ wt. of soil $* 1000 * 77 * 58$

$\mathrm{OM} \%=(\mathrm{B}-\mathrm{S}) * \mathrm{~N} /$ wt. of soil $* 0.67$

Where, $\mathrm{B}=$ Volume of FAS used up for blank titration

$\mathrm{S}=$ Volume of FAS used up for sample

$\mathrm{N}=$ Normality of FAS from blank titration

Wt. $=$ Weight of sample.

Note: Organic matter contains $58 \%$ carbon. Recovery factor for this method is 77 percent. Equivalent weight of carbon is 3 .

$\mathrm{SOC}=$ Organic Carbon Content \%* Soil Bulk Density $\left(\mathrm{gm} / \mathrm{cm}^{3}\right)$ *thickens of horizon

Whereas $\mathrm{SOC}=$ soil organic carbon stock, $\mathrm{C}=$ carbon concentration

$\rho=$ soil bulk density $\left(\mathrm{gm} / \mathrm{cm}^{3}\right) \& d=$ total depth at which the sample was taken $(\mathrm{cm})$.

\section{c. Total carbon calculation}

Following formula was used to calculate the total carbon.

$\mathrm{C}(\mathrm{LU})=\mathrm{C}(\mathrm{AGTB})+\mathrm{C}(\mathrm{AGSB})+\mathrm{C}(\mathrm{BB})+\mathrm{C}(\mathrm{LHG})+\mathrm{SOC}$

Where, $\mathrm{C}(\mathrm{LU})=$ Carbon stock for a land use category

$\mathrm{C}(\mathrm{ABTG})=$ Carbon in above ground tree biomass

$\mathrm{C}(\mathrm{AGSB})=$ Carbon in above ground sapling biomass

$\mathrm{C}(\mathrm{BB})=$ Carbon in below ground biomass

$\mathrm{C}(\mathrm{LHG})=$ Carbon in litter, herb and grass

$\mathrm{SOC}=$ Soil Organic Carbon.

Carbon sequestration potential: The species wise carbon sequestration was estimated using the following formulas:

Carbon increment $=$ total carbon/Age

Carbon sequestration potential $=$ Carbon increment $* 44 / 12$

Total Carbon sequestration potential $=$ Carbon Sequestration potential per stand $*$ Total no. of $\operatorname{stand}^{29}$ 
Monetary value of carbon sequestration= Total carbon sequestration *US\$15(per ton) (The True Cost of Carbon Pollution, 2020).

\section{Spatial data analysis}

The Google earth imagery was geo-referenced and required land use features shape file of Agriculture, Agroforestry, Settlement area, Road and Natural trees was created in the Arc GIS. Next, the map of the study area was overlaid on the geo-referenced image and onscreen digitization was made to map land use land cover based on their geometric boundaries. ${ }^{30}$ Finally, change detection in different land use classes was compared.

Accuracy assessment: Accuracy assessment is an important part of a classification which was evaluated using confusion matrix. The ground truth points of different land use and land cover classes were collected from field and these were overlaid on the digitized map. This was done for classified map of 2020. For the accuracy assessment of map 2015 ground truth points were collected from historical imagery provided by the Google earth and overlaid on the digitized image.

Error of omission (OE) and commission (EC): Error of omission refers to the reference sites that were left out from the correct class in the classified map. The real land cover type was left out or omitted from the classified map. The errors of omissions were calculated by reviewing the reference sites for incorrect classifications. Similarly, the error of commission was calculated by reviewing the classified sites for incorrect classifications.

Overall accuracy and Kappa coefficient: The overall accuracy shows where all referenced sites were classified correctly. Similarly, the Kappa Coefficient is generated from a statistical test to evaluate the accuracy of a classification.

Kappa Coefficient $=($ total accuracy - random accuracy $) /(1$ random accuracy).

Statistical analysis: The One-way ANOVA test Post hoc test was performed to compare the species wise carbon stock in the agroforests.

\section{Result}

\section{Carbon status of agroforestry at ratanpur}

Carbon status in agroforest: The Table 2 shows that descriptive statistics of above ground total carbon, below ground total carbon and total carbon in $\mathrm{kg}$. The estimated highest and lowest total carbon was 3482.41 and $127.39 \mathrm{~kg}$ respectively. The maximum total carbon was $3482.41 \mathrm{~kg} / \mathrm{ha}$ while the minimum was $127.39 \mathrm{~kg} / \mathrm{ha}$. The average and standard error of total carbon was $1555.01 \pm 281.42 \mathrm{~kg}$. The above ground carbon was $1335.22 \pm 249.57 \mathrm{~kg}$, below ground carbon was $219.79 \pm 31.98 \mathrm{~kg}$ while the soil carbon was $53.27 \pm 3.19$. However, the Standard deviation of these parameter.

Table 2 Statistics of carbon stock of agro-forest in farm land

\begin{tabular}{lllllll}
\hline & Mean \pm SE & $\begin{array}{l}\text { Standard } \\
\text { deviation }\end{array}$ & $\begin{array}{l}\text { Sample } \\
\text { variance }\end{array}$ & Range & Minimum & Maximum \\
\hline Above ground carbon $(\mathrm{kg})$ & $1335.22 \pm 249.57$ & 1087.87 & 1183470 & 65.51 & 45.63 & 3025.8 \\
Below ground carbon $(\mathrm{kg})$ & $219.79 \pm 31.98$ & 139.4 & 19434.41 & 396.12 & 60.5 & 456.2 \\
Total carbon $(\mathrm{kg})$ & $1555.01 \pm 281.42$ & 1226.69 & 1504780 & 3355.02 & 127.39 & 3482.41 \\
\hline
\end{tabular}

(Source: Field Survey, 2020)

\section{Species wise number of stand and carbon status}

The highest number of planted tree species was Cinnamomum tamala with 973 which was followed by Michelia champaca with 652 stands, Leucaena leucocephala with 54 stands, Bauhinia

purpurea with 50 stands, Paulownia tomentosa with 41 stands, Melia azadirach with 38 stands, Morus indica and Schima wallichi with 27 stands, Ficus cunia with 22 stands, Artocarpus lakoocha with 14 stands, Mangifera indica and Choerospondias axillaris with 1 stand (Table 3).

Table 3 Species wise number of stands and carbon stock

\begin{tabular}{llll}
\hline & No of stands & Carbon $(\mathbf{K g} /$ stand) & Remarks \\
\hline Melia azadirach & 38 & 14.42 \\
Leucaena leucocephala & 54 & 1.16 \\
Michelia champaca & 652 & 16.55 \\
Ficus cunia & 22 & 4.71 \\
Cinnamomum tamala & 973 & 1.32 \\
Paulownia tomentosa & 41 & 17.61 \\
Bauhinia purpurea & 50 & 1.47 \\
Morus indica & 27 & 2.88 \\
Schima wallichi & 27 & 1.99 \\
Mangifera indica & 1 & 1.57 \\
Choerospondias axillaris & 1 & 9.32 \\
\hline
\end{tabular}

(Source: Field Survey, 2020) 
The highest carbon stock was found around $17.6 \mathrm{~kg} /$ stand of Paulownia tomentosa plantation. This was followed by Michelia champaca with $16.5 \mathrm{~kg} / \mathrm{stand}$. The lowest value of this was found in Leucaena leucocephala with $1.1 \mathrm{~kg} /$ stand (Table 3). Statistically, One-way ANOVA showed that there were significant differences in carbon per stnad among the species since the $\mathrm{p}$ value was less than 0.05. Post hoc test showed that carbon stock per stand of Leucaena leucocephala, Bauhinia purpurea, Cinnamomum tamala and Litsea polyantha was different from carbon stock of other species at $95 \%$ confidence level since the mean carbon values of these species falls under same subset.

\section{Species wise carbon sequestration potential}

Carbon sequestration and monetary value of sapling staged plant: The carbon sequestration in plantation was varying according to species. The monitory value of carbon sequestration was also differed accordingly. Total carbon sequestration was $2057.689 \mathrm{~kg}$ and its monetary value was US\$ 30.863 . The results showed that the highest annual carbon sequestration potential was of Ficus cunia with 4.327 $\mathrm{kg} /$ stand. Since, the number of stands of Michelia champaca was the highest at saplings stage therefore the monetary value of carbon sequestration was found to be highest with US\$22.68/ton.

Carbon sequestration and monetary value of pole staged plant: The result revealed that the highest annual carbon sequestration potential of Paulownia tomentosa at pole stage with $18.63 \mathrm{~kg} / \mathrm{stand}$. Since, Paulownia tomentosa is the only species with large number of poles the monetary of carbon sequestration was found to be highest with US\$3.91. Total carbon sequestration was $475.013 \mathrm{~kg}$ and its monetary value was US\$ 7.122.

Carbon sequestration and monetary value of Sapling $\mathrm{DBH}<\mathbf{5 m}$ staged plant: The species wise carbon sequestration was differed of sapling $\mathrm{DBH}<5 \mathrm{~cm}$ and the monetary value of this were also varied. The results showed that, total carbon sequestration was $213.38 \mathrm{~kg}$ and its monetary value was US\$ 3.201. The highest annual record of carbon sequestration was $0.38 \mathrm{~kg} / \mathrm{stand}$ of Morus indica while the number of stands was the highest of Cinnamomum tamala so the carbon sequestration was the highest $141.15 \mathrm{~kg}$ and its monetary value was US\$2.12 (Table 4).

Table 4 The highest annual record of carbon sequestration

\begin{tabular}{|c|c|c|c|c|c|c|c|c|c|}
\hline \multirow[t]{2}{*}{ Species } & $\begin{array}{l}\text { Carbon } \\
\text { sequestration } \\
\text { potential (kg/ } \\
\text { stand) }\end{array}$ & \multirow[t]{2}{*}{$\begin{array}{l}\text { Total Carbon } \\
\text { sequestration } \\
\text { potential (kg) }\end{array}$} & \multirow{2}{*}{$\begin{array}{l}\text { Monetary } \\
\text { value of } \\
\text { carbon } \\
\text { sequestration } \\
\text { (US\$) }\end{array}$} & \multirow{2}{*}{$\begin{array}{l}\begin{array}{l}\text { Carbon } \\
\text { sequestration } \\
\text { potential (kg/ } \\
\text { stand) }\end{array} \\
\text { Pole Stage }\end{array}$} & \multirow[t]{2}{*}{$\begin{array}{l}\text { Total Carbon } \\
\text { sequestration } \\
\text { potential }(\mathrm{kg})\end{array}$} & \multirow{2}{*}{$\begin{array}{l}\text { Monetary } \\
\text { value of } \\
\text { carbon } \\
\text { sequestration } \\
\text { (US\$) }\end{array}$} & \multirow{2}{*}{$\begin{array}{l}\begin{array}{l}\text { Carbon } \\
\text { sequestration } \\
\text { potential (kg/ } \\
\text { stand) }\end{array} \\
\text { Sapling stage }\end{array}$} & \multirow[t]{2}{*}{$\begin{array}{l}\text { Total Carbon } \\
\text { sequestration } \\
\text { potential }(\mathrm{kg})\end{array}$} & \multirow{2}{*}{$\begin{array}{l}\text { Monetary } \\
\text { value of } \\
\text { carbon } \\
\text { sequestration } \\
\text { (US } \$ \text { ) }\end{array}$} \\
\hline & Tree stage & & & & & & & & \\
\hline Melia azadirach & 3.263 & 97.9 & 1.468 & 10.267 & 82.13 & 1.232 & & & \\
\hline $\begin{array}{l}\text { Michelia } \\
\text { champaca }\end{array}$ & 3.19 & 1512.06 & 22.68 & 13.457 & 121.11 & 1.82 & 0.348 & 58.87 & 0.88 \\
\hline Ficus cunia & 4.327 & 95.187 & 1.428 & & & & & & \\
\hline $\begin{array}{l}\text { Bauhinia } \\
\text { purpurea }\end{array}$ & 1.008 & 19.158 & 0.287 & & & & 0.29 & 9.093 & 0.14 \\
\hline $\begin{array}{l}\text { Cinnamomum } \\
\text { tamala }\end{array}$ & 1.052 & 33.675 & 0.505 & & & & 0.15 & 141.15 & 2.12 \\
\hline $\begin{array}{l}\text { Paulownia } \\
\text { tomentosa }\end{array}$ & 2.677 & 69.593 & 1.044 & 18.63 & 260.77 & 3.91 & & & \\
\hline Morus indica & 2.578 & 59.286 & 0.889 & & & & 0.38 & 1.525 & 0.02 \\
\hline $\begin{array}{l}\text { Artocarpus } \\
\text { lakoocha }\end{array}$ & 2.567 & 35.933 & 0.539 & & & & & & \\
\hline Schima wallichi & 3.703 & 74.067 & 1.111 & & & & 0.183 & 1.283 & 0.02 \\
\hline Litsea polyantha & 2.64 & 7.92 & 0.119 & & & & 0.33 & 1.32 & 0.019 \\
\hline Mangifera indica & 1.43 & 1.43 & 0.021 & & & & & & \\
\hline $\begin{array}{l}\text { Choerospondias } \\
\text { axillaris }\end{array}$ & & & & 11.003 & 11.003 & 0.16 & & & \\
\hline Total & & 2057.69 & 30.863 & & 475.013 & 7.122 & & 213.38 & 3.201 \\
\hline
\end{tabular}

\section{Soil carbon stock at study site}

From 19 farmers of the experimental site whose soil carbon stock was analyzed, the average soil carbon stock $\pm \mathrm{SE}$ was found to be $52.9 \pm 3.21$ ton per ha which was greater than that of average $\pm \mathrm{SE}$ of 4 control site i.e. $50.34 \pm 3.82$ ton per ha. The SOC of forest depend upon various biotic and abiotic factors such as micro-climate, faunal diversity, land use, land management and crops. ${ }^{31}$ It shows that the mean of the soil organic carbon was decreased along with the depth of the soil.
The clear trend was seen in soil carbon according to the soil depth. It was the highest in $0-10 \mathrm{~cm}$ while the lowest value was in $20-30 \mathrm{~cm}$ depth in all the control site and experimental site. The soil organic carbon (SOC) was decreased with the increase in soil depth in all the control site (Agriculture land) and experimental site (Agroforestry land). All the agroforestry land and the agriculture land contained greater SOC in the upper layer $0-10 \mathrm{~cm}$ followed by $10-20 \mathrm{~cm}$ and 20 $30 \mathrm{~cm}$ depth respectively (Table 5). 
Table 5 Statistics of soil organic carbon of experimental and control site

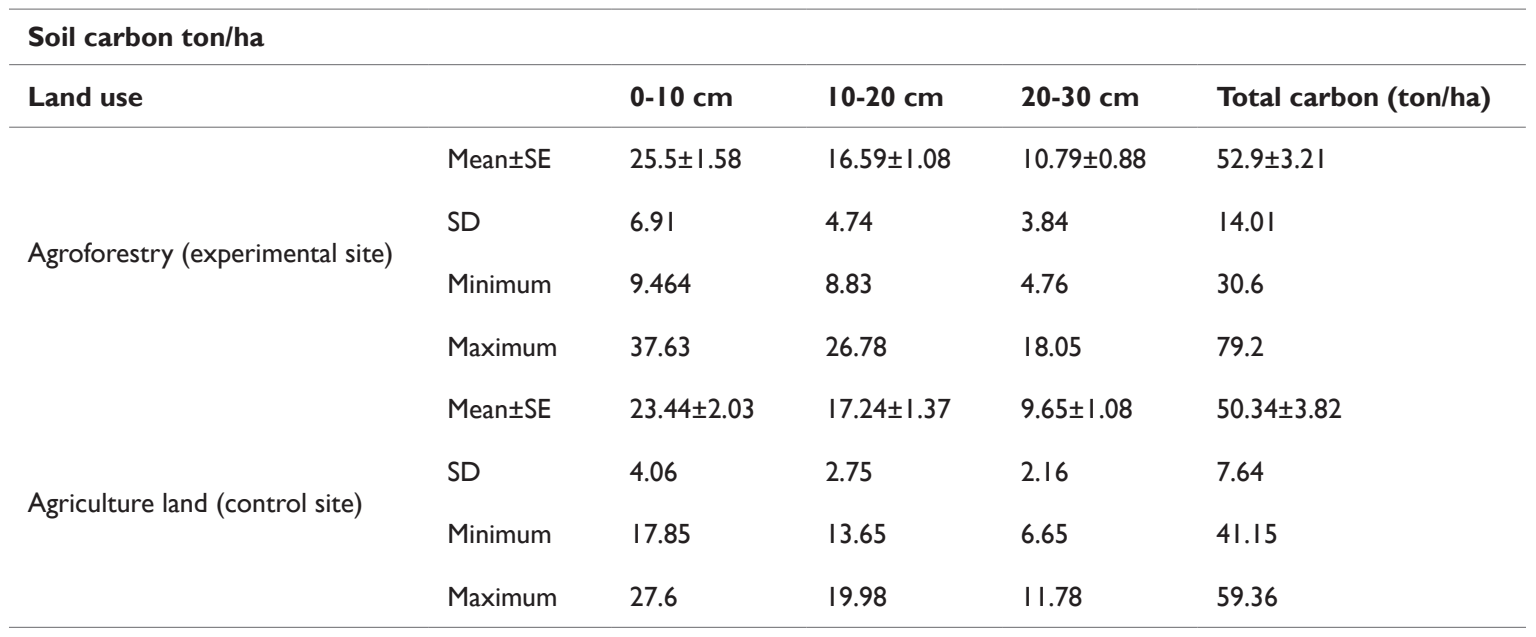

(Source: Field Survey, 2020)

Land use land cover dynamics of agroforestry between 2015 and 2020 at ratanpur:

The digitization of the google earth image 2020 showed five thematic classes namely agriculture, agroforestry, natural trees, settlement areas and others. Specifically, Agriculture land was 3.6 ha $(18.01 \%)$, Agroforestry was 6.2 ha $(31.03 \%)$, Natural trees area was 4.67 ha $(23.37 \%)$, Settlement was 0.03 ha $(0.15 \%)$ and other area was 5.48 ha $(27.42 \%)$ of the total study area but agriculture was
10.12 (50.65), agroforestry was 0 ha, natural trees was $4.45(22.27 \%)$, settlement areas was 0.024 ha $(0.12 \%)$ and others was $5.38(26.9 \%)$.

Comparison of land use land cover classes between 2015 and 2020 showed that there was negative change in Agriculture class but this was positive change in other land use and land cover thematic classes. Mainly agriculture land use class was reduced by $6.52(32.64 \%)$ which was converted into mainly agroforest (6.2 ha, 31.03\%) and Natural trees $(0.22$ ha, $1.1 \%)$ and so on (Table 6$)$.

Table 6 Change area of Ratanpur between 2015 and 2020

\begin{tabular}{lllllll}
\hline \multirow{2}{*}{ Land use land cover class } & \multicolumn{2}{l}{ Classification of 2015} & \multicolumn{2}{l}{ Classification of 2020 } & \multicolumn{2}{c}{ Changes between 2015 \& 2020 } \\
\cline { 2 - 7 } & Area (ha) & Percentage & Area (ha) & Percentage & Area (ha) & Percentage \\
\hline Agriculture & 10.12 & 50.65 & 3.6 & 18.01 & -6.52 & -32.64 \\
Agroforestry & 0 & 0 & 6.2 & 31.03 & 6.2 & 31.03 \\
Natural trees & 4.45 & 22.27 & 4.67 & 23.37 & 0.22 & 1.1 \\
Settlement area & 0.024 & 0.12 & 0.03 & 0.15 & 0.006 & 0.03 \\
Others & 5.38 & 26.9 & 5.48 & 27.42 & 0.1 & 0.52
\end{tabular}

(Source: Field Survey, 2020)

Carbon increment: The conversion of agriculture land to agroforest land resulted in the remarkable increase in carbon densities. It was only 509.442 ton carbon in 2015 which was reached to 606.916 in 2020. Thus the total increase in carbon stock in agroforest was 97.475ton (Table 7) (Figure 2) (Figure 3).

Table 7 Increment in carbon

\begin{tabular}{lllll}
\hline & 2015 & & 2020 & \\
\cline { 2 - 5 } & Agriculture & Agroforest & Agriculture & Agroforest \\
\hline Area ha & 10.12 & 0 & 3.6 & 6.2 \\
C ton/ha & 50.34 & 0 & 50.34 & 68.66 \\
Total C ton & $509.44 I$ & 0 & 181.224 & 425.692 \\
Total C: 606.916 ton in 2020. Increase in C between 2015 \& 2020=97.475 tom & \\
\hline
\end{tabular}

(Source: Field Survey, 2020) 


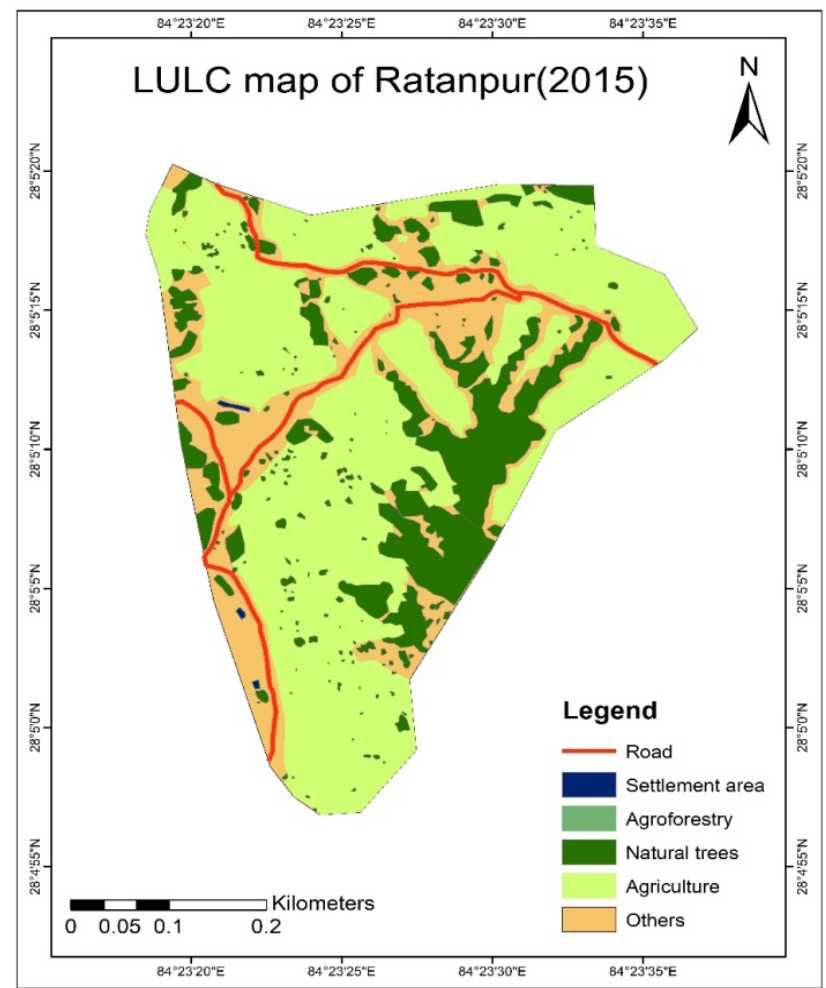

Figure 2 Land-use land-cover map of Ratanpur (2015).

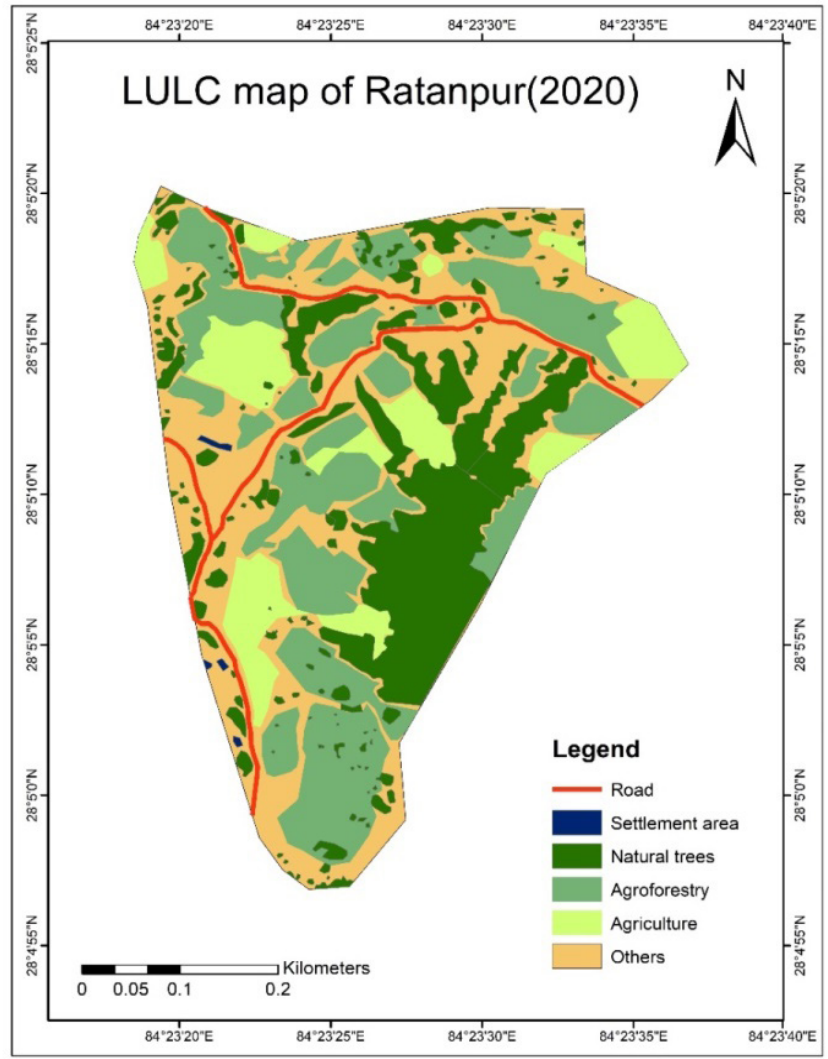

Figure 3 Land-use land-cover map of Ratanpur (2020).

Accuracy assessment for map of 2015 and 2020: The overall accuracy for 2015 was $90.91 \%$ with Kappa coefficient 0.86 . So, Kappa of 0.86 means there is $86 \%$ better agreement than by chance alone in 2015. The summary of classification accuracy with producer's accuracy (PA), User's accuracy (UA), Commission error (CE) and omission errors (OE) is presented below in Table 8. The 
overall accuracy for 2020 was $80.65 \%$ with Kappa coefficient 0.74 . So, Kappa of 0.74 means there is $74 \%$ better agreement than by chance alone in 2020 . The summary of classification accuracy with producer's accuracy (PA), User's accuracy (UA), Commission error (CE) and omission errors (OE) is presented below in Table 8 .

Table 8 Summary of classification accuracy (\%) for 2015

\begin{tabular}{|c|c|c|c|c|}
\hline \multicolumn{5}{|c|}{ Accuracy Assessment of map of 2015} \\
\hline Thematic Class & Producer's accuracy & User accuracy & Commission error & Omission error \\
\hline Natural trees & 100 & 100 & 0 & 0 \\
\hline Agriculture & 87.5 & 100 & 0 & 12.5 \\
\hline Agro forestry & 0 & 0 & 0 & 0 \\
\hline Road & 100 & 50 & 50 & 0 \\
\hline Settlement & 100 & 50 & 50 & 0 \\
\hline Others & 80 & 100 & 0 & 20 \\
\hline \multicolumn{5}{|c|}{ Accuracy Assessment of map of 2020} \\
\hline Natural trees & 90 & 90 & 20 & 10 \\
\hline Agriculture & 83.33 & 100 & 20 & 16.67 \\
\hline Agro forestry & 66.67 & 85.71 & 28.57 & 50 \\
\hline Road & 100 & 33.33 & 66.67 & 50 \\
\hline Settlement & 0 & 50 & 100 & 0 \\
\hline Others & 75 & 75 & 100 & 60 \\
\hline
\end{tabular}

(Source: Field Survey, 2020)

\section{Discussion}

This research describes about the carbon sequestration potential of agroforestry practices and comparing the soil organic carbon of agroforestry land with agriculture land, addresses land use land cover dynamics of study area Ratanpur, Tanahun during the period 2015 and 2020. The carbon stock in the experimental site denoted was found to be higher with 68 ton/ha than other because the site contained large number of trees with greater diameter and height and with greater number of planted plants. The carbon stock was generally higher in plantation site. ${ }^{32,33}$ The influential role was found in carbon sequestration in agroforest area ${ }^{34}$ in the study site.

The carbon status of Paulownia tomentosa was the highest carbon stock which was found to be $17.6 \mathrm{~kg}$ stand because among all the planted species Paulownia tomentosa was the fast-growing species which had reached the pole size having the highest diameter and height.

Carbon sequestration potential of pole is greater than that of saplings because they sequester more carbon than others. Since, the planted species have not been grown to trees and few species has been to pole more carbon will be sequestered in the future from the saplings. Sized trees have better carbon sequestration potential than young plants and saplings. ${ }^{35}$

Soil carbon stock of the agroforestry land which was denoted by the experimental site was found to have higher potential to sequester carbon than that of agriculture, pasture or field crops which was denoted by the control site. This conjecture is based on the notion that tree incorporation in cropland pasture land would result in greater net above ground as well as below ground $\mathrm{C}$ sequestration. ${ }^{36}$ The above result also reveals that the carbon is increased when converting agriculture land to agroforestry land as the number of trees and soil carbon is increased. ${ }^{37,38}$ Carbon increment of pole, sapling, differ for varying species. Carbon increment of pole is seen maximum in Pauwlonia tomentosa with $13.45 \mathrm{~kg} /$ plant. Likewise, carbon increment of sapling is seen maximum in Schima wallichi with $2.72 \mathrm{~kg} / \mathrm{plant}$.

The soil carbon was decreased with respect to soil depth in all selected control site and experimental site. All the sites contained greater SOC in the upper layer $0-10 \mathrm{~cm}$ followed by $10-20$ and 20 $30 \mathrm{~cm}$ depth. This may be attributed by the fact that higher amount of humus was present in the top layer of the soil profile and decreasing the organic matter with the increase in soil depth. Likewise, the study shows that the both the agriculture land and agroforestry land in soil carbon with the increase in soil depth was supported different authors. ${ }^{39-43}$ They found the maximum amount of SOC in the upper layer $0-10 \mathrm{~cm}$ as compared to the lower layer $80-100 \mathrm{~cm}$.

Monetary value of carbon is different for all the poles and saplings of different species. The monetary value of carbon for sapling is US\$22.68 for Michelia champaca. Monetary value for pole was US\$3.92 for Paulownia tomentosa. Likewise, monetary value for sapling DBH $<5 \mathrm{~cm}$ was less with US\$2.12 per ton for Cinnamomum tamala. The annual increment can be used to determine the monetary multiplying with market rate of carbon. ${ }^{44}$ The value of carbon in agroforestry depends up on total carbon sequestration and price of carbon credit as well. Thus, the value of carbon sequestration in the agroforest was varying.

Land use land cover map of Ratanpur showed that agriculture area was reduced by $46.86 \%$, Agroforestry was increased to $48.4 \%$ since there was no any agroforestry practices adopted in 2015 . Natural trees in the study area is increased by $4.63 \%$ whereas, settlement area is increased by $0.069 \%$ because local people have established the goat farm in Ratanpur. The land cover change between 2015 and 2020 had an impact on the total carbon stock in the study area. As land use change has been detected as one of the major sources for anthropogenic carbon emissions, studies quantifying these changes 
should also have a link to reasons behind such change. ${ }^{45}$ Land uses with woody perennials have high carbon stock than those without. Hence, conservation based production systems with inclusion of woody perennials helps to enhance the carbon sequestration. ${ }^{38}$

Accuracy assessment of the land use and land cover map showed that the land use land cover map of 2015 is $90.91 \%$ accurate with Kappa coefficient 0.86 because almost all the lands were agriculture land and was easy to identify in the image. Whereas, the land use land cover map of 2020 was $80.65 \%$ with Kappa coefficient of 0.74 . The accuracy of 2020 was less than 2015, this might be because the planted agroforestry plants in 2020 were maximum of age 4 yrs. and in this age most of the plants were not fully grown and had not attained the maximum height that can be visible aerially.

The study shows that carbon stock in agriculture land varies with the carbon stock in agroforestry land. Soil carbon was found to be slightly higher in agroforestry land than in the agriculture land. The higher soil organic carbon stock recorded in the agroforestry land was mainly because of the biomass inputs and organic fertilizer used during plantation. Increment in the tree component and on agricultural land is an achievable and relatively fast route for increment in carbon sequestration. ${ }^{46}$

\section{Conclusion and recommendations}

The agroforest practice was done since 2016 at Ratanpur, Nepal. These agroforests sequestrate more carbon than the agriculture practice. The application of carbon increment in agroforests showed the area, location and carbon dynamics at Ratanpur, Nepal. The highest carbon stock/stand was of Paulownia tomentosa but it was the lowest of Leucaena leucocephala. The highest number of stands planted was Cinnamomum tamala so total carbon sequestration was highest and its monetary value was also the highest. The highest annual carbon sequestration potential per stand was of Ficus cunia but the total highest carbon sequestration potential was of Michelia champaca at saplings stage therefore the estimated monetary value was also the highest. The highest carbon sequestration potential was of Paulownia tomentosa at pole stage and so as the monetary value. The highest carbon sequestration of $\mathrm{DBH}<5 \mathrm{~cm}$ was of Cinnamomum tamala and the monetary value was also the highest. Agroforestry practice was not adopted in 2015 so there was no agroforest thematic class in the map which was remarkably observed in thematic map of 2020. The mean carbon stock per stand of Leucaena leucocephala, Bauhinia purpurea, Cinnamomum tamala and Litsea polyantha were significantly different from carbon stock of other species.

The agroforestry in small scale farmers is potential for carbon sequestration and it will be applied to claim the carbon credit under REDD + mechanism. Use of high resolution imagery from google earth platform and digitation will be reliable tool to assess the carbon which will be able to use for carbon monitoring. Intensive research on assessing the carbon stock on different agroforestry model will further scope of study.

\section{Acknowledgments}

None.

\section{Funding}

None.

\section{Conflicts of interest}

All author listed here declare no conflict of interest exists.

\section{References}

1. Ellis EA, Bentrup G, Schoeneberger MM. Computer-based tools for decision support in agroforestry: Current state and future needs.

2. Lal R. Agricultural activities and the global carbon cycle. Nutrient cycling in agroecosystems. 2004;70(2):103-116.

3. Sharma R, Chauhan S, Tripathi A. Carbon sequestration potential in agroforestry system in India: An analysis for carbon project. Agroforestry Systems. 2015.

4. Paudel D, Tiwari K, Bajracharya R, et al. Agroforestry system: an opportunity for carbon sequestration and climate change adaptation in the mid-hills of Nepal. Octa Journal Of Environmental Research. 2017.

5. Lal R. Carbon sequestration. Philosophical transactions of the royal society of London. Series B, Biological Sciences. 2008;363:815-830.

6. Mackey B, Prentice I, Steffen W, et al. Untangling the confusion around land carbon science and climate change mitigation policy. Nature Climate Change. 2013;3:552-557.

7. Nair P, Nair V, Mohan Kumar B, et al. Carbon sequestration in agroforestry systems. Advances in Agronomy. 2010;108:237-307.

8. Pandit BH, Thapa GB. Poverty and resource degradation under different common forest resource management systems in the mountains of Nepal. Society \& Natural Resources. 2004;17(1):1-16.

9. Dhungana SP, Oli BN, Mandal RA. Claiming a bird in hand: economic potential of plantation in nepal under clean development mechanism. Journal of Forest and Livelihood. 2007;6(1), 18-27.

10. Tiwari KR, Bajracharya RM, Raut N, et al. Agroforestry system: an opportunity for carbon sequestration and climate change adaptation in the mid-hills of Nepal. Octa Journal of Environmental Research. 2017;5(1).

11. Köhl M, Neupane PR, Mundhenk P. REDD+ measurement, reporting and verification-A cost trap? Implications for financing REDD + MRV costs by result-based payments. Ecological Economics. 2020;168:106513.

12. Woo J, Fatima R, Kibert C., et al. Applying blockchain technology for building energy performance measurement, reporting, and verification (MRV) and the carbon credit market: A review of the literature. Building and Environment. 2021.

13. Thakur JK, Singh SK, Ekanthalu VS. Integrating remote sensing, geographic information systems and global positioning system techniques with hydrological modeling. Applied Water Science. 2017;7(4):15951608 .

14. Abbas I. Mapping land use-land cover and change detection in kafur local government, Katsina, Nigeria (1995-2008) using remote sensing and gis. Research Journal of Environmental and Earth Sciences. 2010.

15. Rawat JS, Kumar M. Monitoring land use/cover change using remote sensing and GIS techniques: A case study of Hawalbagh block, district Almora, Uttarakhand, India. The Egyptian Journal of Remote Sensing and Space Science. 2015;18(1):77-84.

16. Knorn J, Rabe A, Radeloff V, et al. Land cover mapping of large areas using chain classification of neighboring Landsat satellite images. Remote Sensing of Environment. 2009;113:957-964.

17. Fisher G, Amos C, Bookhagen B, et al. Channel widths, landslides, faults, and beyond: The new world order of high-spatial resolution Google Earth imagery in the study of earth surface processes. Special Paper of the Geological Society of America. 2012;492:1-22.

18. Abdelaty E. Land use change detection and prediction using high spatial resolution Google Earth imagery and GIS techniques: A study on ElBeheira Governorate, Egypt. 2016.

19. 2006 IPCC Guidelines for National greenhouse gas inventories-IPCC. 2006. 
20. Wibowo A, Salleh KO, Frans FT, et al. Spatial temporal land use change detection using google earth data. IOP Conference Series: Earth and Environmental Science. 2016;47:012031.

21. Kimambo NE, L'Roe J, Naughton-Treves L, et al. The role of smallholder woodlots in global restoration pledges-Lessons from Tanzania. Forest Policy and Economics. 2020;115:102144.

22. Chave J, Andalo C, Brown S, et al. Tree allometry and improved estimation of carbon stocks and balance in tropical forests. Oecologia. 2005;145(1):87-99.

23. Tamrakar PR. Nepal, Ministry of Forest and Soil Conservation, Natural Resource Management Sector Assistance Programme (Nepal), Natural Resource Management Sector Assistance Programme (Nepal), \& Tree Improvement and Silviculture Component. Biomass and volume tables with species description for community forest management. Ministry of Forest and Soil Conservation : Natural Resource Management Sector Assistance Programme. 2000

24. Macdicken K. A guide to monitoring carbon storage in forestry and agroforestry projects. 1997 .

25. Andreae MO, Merlet P. Emission of trace gases and aerosols from biomass burning. Global Biogeochemical Cycles. 2001;15(4):955-966.

26. Misra R. Ecology workbook. Oxford \& IBH Publishing Company; 1968.

27. Walkley A, Black IA. An examination of the degtjareff method for determining soil organic matter, and a proposed modification of the chromic acid titration method. Soil Science. 1934;37(1):29-38.

28. Chhabra A, Palria S, Dadhwal V. Growing stock-based forest biomass estimate for India. Biomass and Bioenergy. 2002;22:187-194.

29. Tan Z, Zhang Y, Yu G, et al. Carbon balance of a primary tropical seasonal rain forest. Journal of Geophysical Research: Atmospheres. 2010;115(D4).

30. Gangaraju M, Anitha P, Krishna TV, et al. Spatio-temporal changes of land use/land cover of pindrangi village using high resolution satellite imagery. Journal of Remote Sensing \& GIS. 2017;06(02).

31. Shrestha BM, Singh B. Soil and vegetation carbon pools in a mountainous watershed of Nepal. Nutrient Cycling in Agroecosystems. 2008;81:179191.

32. Pragasan LA, Karthick A. Carbon stock sequestered by tree plantations in university campus at Coimbatore, India. International journal of environmental sciences. 2013;3(5):1700-1710.

33. Peng W, Pukkala T, Jin X, et al. Optimal management of larch (Larix olgensis A. Henry) plantations in Northeast China when timber production and carbon stock are considered. Annals of forest science. 2018;75(2):115 .
34. Liao C, Luo Y, Fang C, et al. Ecosystem carbon stock influenced by plantation practice: implications for planting forests as a measure of climate change mitigation. PloS one. 2010;5(5):e10867.

35. Tagupa C, Lopez A, Caperida F, et al. Carbon Dioxide (co2) Sequestration Capacity of Tampilisan Forest.

36. Nair P, Mohan Kumar B, Nair V. Agroforestry as a strategy for carbon sequestration. Journal of Plant Nutrition and Soil Science. 2009;172:10 23

37. Chatterjee N, Nair PR, Chakraborty S, et al. Changes in soil carbon stocks across the Forest-Agroforest-Agriculture/Pasture continuum in various agroecological regions: A meta-analysis. Agriculture, ecosystems \& environment. 2018;266:55-67.

38. Toru T, Kibret K. Carbon stock under major land use/land cover types of Hades sub-watershed, eastern Ethiopia. Carbon Balance and Management. 2019;14(1):7.

39. Khanal Y, Sharma R, Upadhyaya C. Soil and vegetation carbon pools in two community forests of Palpa district, Nepal. Banko Janakari. 1970;20(2):34-40.

40. Sah S, Sharma S, Mandal R. Comparison of carbon stock in Chure, Bhawar and Terai, Nepal (A study from Mahottary district). International Journal of Scientific and Engineering Research. 2019;10:80-93.

41. Maharjan M. Soil Carbon and nutrient status of rangeland in upper mustang. Institute of Forestry Pokhara, Nepal, Tribhuvan University, a thesis submitted in partial fulfillment of the requirements for the degree of master of science in watershed management. 2010.

42. Ranjitkar NB. Carbon stock estimation in lower temperate forest in Shivapuri Nagarjun National Park, Nepal [Thesis, Central Department of Botany, Tribhuvan University Kirtipur, Kathmandu, Nepal]. 2010.

43. Dutta IC, Mandal RA, Acharya N. Potential income of community forests from forest carbon sequestration (A case study of Mahottary district, Nepal).

44. Jeuland MA, Pattanayak SK. Benefits and costs of improved cookstoves: assessing the implications of variability in health, forest and climate impacts. PloS one. 2012;7(2):e30338.

45. Meyer WB, Turner BL. Changes in land use and land cover: a global perspective. 1st edn. Cambridge University Press; 1994.

46. Zomer RJ, Neufeldt H, Xu J, et al. Global tree cover and biomass carbon on agricultural land: the contribution of agroforestry to global and national carbon budgets. Scientific Reports. 2016;6(1):29987. 